BARTOSZ WALICKI - SOKOŁÓW MAŁOPOLSKI

\title{
KONFERENCJA NAUKOWA „KS. LUDWIK RUCZKA (1814-1896) - OJCIEC SYBIRAKÓW”. KOLBUSZOWA, 29 STYCZNIA 2016 R.
}

W 2016 roku społeczność ziemi kolbuszowskiej przeżywa 120. rocznicę śmierci proboszcza kolbuszowskiej parafii pw. Wszystkich Swiętych, z drugiej połowy XIX wieku, ks. Ludwika Ruczki. Stało się to okazją do zorganizowania konferencji naukowej Ks. Ludwik Ruczka (1814-1896) - Ojciec Sybiraków. Odbyła się ona w piątek 29 stycznia 2016 r. w Miejskiej i Powiatowej Bibliotece Publicznej w Kolbuszowej.

Bohater spotkania, ks. Ludwik Ruczka, pozostawał wieloletnim proboszczem kolbuszowskim. Przez pewien czas piastował mandat posła do Sejmu Krajowego Galicji oraz posła do Rady Państwa w Wiedniu. Był zasłużonym duszpasterzem. W dziejach regionu, a nawet kraju, zapisał się jednak poprzez swoją działalność na rzecz powstańców styczniowych. Dzięki jego staraniom uratowanych zostało kilkuset uczestników zrywu narodowego z roku 1863 z terenu Galicji. Dotyczyło to zarówno Polaków osadzonych przez władze austriackie, jak i zesłańców na Sybir. Zesłańców i weteranów wracających do kraju wspomagał finansowo. Wspierał również uczestników polskich powstań narodowych we Francji. Z tej przyczyny już przez współczesnych określany był jako „Ojciec Sybiraków”.

Pamięć o ks. Ludwiku Ruczce jest kultywowana w Kolbuszowej do dziś. Niemała w tym zasługa miejscowych społeczników. Dotyczące go artykuły naukowe publikowane były m.in. na łamach „Rocznika Kolbuszowskiego"1 i w regionalnych publikacjach książkowych ${ }^{2}$, ale także w Polskim słowniku bio-

${ }^{1}$ H. Dudzińska, Ksiadz Ludwik Ruczka, proboszcz kolbuszowski - , Ojciec Sybiraków”, „Rocznik Kolbuszowski”, 2 (1987) s. 31-44; K. Haptaś, Życiorys proboszcza kolbuszowskiego ks. Ludwika Ruczki opublikowany po jego śmierci na łamach krakowskiego dziennika „Czas” (2 XII 1896 r.), „Rocznik Kolbuszowski”, 11 (2011) s. 83-89.

${ }^{2}$ K. Haptaś, Propozycja objęcia probostwa mieleckiego dla ks. Ludwika Ruczki (w 1867 roku). Przyczynek do biografii duchownego, w: Parafia Kolegiacka Wszystkich Świętych w Kolbuszowej $w$ latach 1510-2010. Studia, szkice i materiaty, red. S. Zych, Kolbuszowa 2010, s. 302-305; W. Mroczka, Biogramy kolbuszowskich proboszczów z lat 1786-1997, w: tamże, s. 291-294. 
graficznym ${ }^{3}$ oraz półroczniku „Archiwa, Biblioteki i Muzea Kościelne”4. Sylwetka duchownego była tematem Turnieju Wiedzy o Historii Regionu im. prof. Haliny Dudzińskiej, organizowanego przez Miejską i Powiatową Bibliotekę Publiczną w Kolbuszowej, Muzeum Kultury Ludowej w Kolbuszowej oraz Regionalne Towarzystwo Kultury im. Juliana Macieja Goslara w Kolbuszowej. Imieniem ks. Ruczki nazwano jedną z ulic w tym mieście. Rok 2000 ustanowiony został w regionie Rokiem ks. Ludwika Ruczki. Kapłan jest również honorowym obywatelem miasta.

Pogłębieniu refleksji na temat postaci ks. Ludwika Ruczki służyła styczniowa konferencja. Zorganizowały ją: Ośrodek Badań nad Polonią i Duszpasterstwem Polonijnym KUL, Parafia kolegiacka pw. Wszystkich Świętych w Kolbuszowej oraz miejscowa książnica. Partnerem konferencji była Biblioteka Uniwersytecka KUL. Patronatu honorowego udzielili: bp Jan Wątroba, poseł na Sejm RP Zbigniew Chmielowiec, starosta kolbuszowski Józef Kardyś i burmistrz kolbuszowski Jan Zuba. Patronami medialnymi były natomiast: tygodnik „Niedziela Rzeszowska” i lokalny miesięcznik „Ziemia Kolbuszowska”.

Obrady konferencyjne poprzedziło złożenie kwiatów na grobie ks. Ludwika Ruczki na cmentarzu kolbuszowskim. Następnie w miejscowym kościele kolegiackim odprawiona została msza św. w intencji duchownego. Przewodniczył jej bp Edward Białogłowski, zaś w koncelebrę włączyło się kilku kapłanów. W liturgię dnia oraz motyw, który zgromadził zebranych, wprowadził dziekan dekanatu kolbuszowskiego wschodniego ks. Kazimierz Osak. Słowo Boże wygłosił proboszcz kolbuszowski ks. Lucjan Szumierz. Na koniec krótkie słowo skierował do obecnych bp Edward Białogłowski.

Miejscem konferencji była Czytelnia im. Dr. Kazimierza Skowrońskiego. Zadania moderatora spełnił ks. dr Sławomir Zych z Katolickiego Uniwersytetu Lubelskiego Jana Pawła II, zarazem redaktor naczelny „Rocznika Kolbuszowskiego". Sympozjum zgromadziło licznych słuchaczy. Nie brakło wśród nich wspomnianych kapłanów. Obecni byli przedstawiciele władz samorządowych: starosta kolbuszowski Józef Kardyś i burmistrz gminy kolbuszowskiej Jan Zuba. Przybyli dyrektorzy i pracownicy jednostek powiatowych, dyrektorzy szkół, pracownicy instytucji kultury, działacze społeczni, młodzież.

Wszystkich przybyłych do książnicy powitał jej dyrektor, Andrzej Jagodziński. Wspomniał on o spotkaniu sprzed kilku lat:

Pani docent Magdalena Micińska wygłosiła wtedy referat na temat księdza Ruczki, jako opiekuna Sybiraków. Zapowiedziała też, że przygotowuje biografię księdza Ruczki, ponieważ ta postać nie funkcjonuje w obiegu naukowym. Obecnie, dzięki determinacji autorów oraz proboszcza kolegiaty kolbuszowskiej ks. Lucjana Szumierza i przy wydatnym wsparciu opiekuna naukowego kolegiaty ks. dr. Sławomira Zycha doczekaliśmy się dwóch publikacji o ks. Ruczce.

${ }^{3}$ B. Kumor, Ruczka Ludwik, w: Polski Stownik Biograficzny, t. 32, Wrocław-Warszawa-Kraków 1991, s. 595-597.

${ }^{4}$ K. Haptaś, Ks. Ludwik Ruczka (1814-1896), proboszcz kolbuszowski, dziekan mielecki, poset Sejmu Krajowego we Lwowie i Wiedeńskiej Rady Państwa, „Ojciec” Sybiraków. W 115. rocznice śmierci, „Archiwa, Biblioteki i Muzea Kościelne”, 96 (2011) s. 345-347. 
O prowadzenie dalszej części spotkania naukowego poproszony został pracownik naukowy Ośrodka Badań nad Polonią i Duszpasterstwem Polonijnym KUL, a zarazem redaktor naczelny „Rocznika Kolbuszowskiego” ks. Sławomir Zych. Powitał on uczestników sympozjum. Na ręce biskupa pomocniczego diecezji rzeszowskiej dr. Edwarda Białogłowskiego złożył natomiast podziękowanie za wspólne przywracanie pamięci o księdzu Ludwiku Ruczce. Odczytał też okolicznościowe pismo skierowane do organizatorów przez rektora Katolickiego Uniwersytetu Lubelskiego ks. prof. dra hab. Antoniego Dębińskiego. Przekazano również pozdrowienia od posła Zbigniewa Chmielowca oraz dyrektor Biblioteki Uniwersyteckiej KUL Barbary Zezuli. W imieniu zaproszonych gości głos zabrał burmistrz Kolbuszowej Jan Zuba. Zaznaczył on:

Dzisiejsza konferencja poświęcona ks. Ludwikowi Ruczce jest kolejnym krokiem na drodze przywracania naszej pamięci tej niezwykłej postaci.

Wprowadzenia w tematykę konferencji dokonał dr hab. Jacek Gołębiowski, dyrektor Ośrodka Badań nad Polonią i Duszpasterstwem Polonijnym KUL. Zwrócił on uwagę:

Ks. Ludwik Ruczka przeszedł do pamięci jako Ojciec Sybiraków. Na miano to zasłużył, ratując kilkaset osób, zesłanych galicyjskich powstańców styczniowych, ale też Polaków osadzonych przez władze austriackie w więzieniach lokalnych. Pomagał finansowo zesłańcom, a także tym, którzy wrócili z zesłania. Pomagał również weteranom polskich powstań narodowych we Francji. Dzisiejsze referaty obejmą tematy związane z postacią księdza Ruczki, ale stanowiące tło jego działań. Nie stracimy jednak z oczu sylwetki tego wielkiego, szlachetnego i bardzo skromnego człowieka, a dzięki tej konferencji uda się nam upowszechniać wiedzę o tym kapłanie.

Podczas spotkania wygłoszonych zostało siedem referatów i komunikatów. Pierwszy temat dotyczył Polaków na Syberii. Opracował go dr Jacek Magdoń z Liceum Ogólnokształcącego im. ks. Piotra Skargi w Sędziszowie Małopolskim. $Z$ powodu nieobecności autora, jego referat odczytany został przez bibliotekarza Grzegorza Mazana. Jako drugi wystąpił ks. dr Roman Nir z Instytutu Historii i Archiwistyki Polonijnej w Chicago. Ukazał on szczegóły pomocy amerykańskiej hierarchii kościelnej dla Polaków w latach 1940-1948. Zagadnienie to dotyczyło niejako kontynuacji i spuścizny działań podejmowanych przez ks. Ludwika Ruczkę wiek wcześniej. Trzecim prelegentem, który nakreślił kontekst historyczny aktywności Ojca Sybiraków był ks. dr hab. Józef Szymański z Włocławka. Skupił się on na syberyjskich losach kapłanów diecezji kujawsko-kaliskiej po powstaniu styczniowym.

Mgr Krzysztof Haptaś z Muzeum Regionalnego w Mielcu omówił duszpasterską i społeczno-polityczną posługę ks. Ludwika Ruczki w Galicji i w stolicy monarchii habsburskiej. Następnie mgr Wojciech Mroczka z Regionalnego Towarzystwa Kultury im. J. M. Goslara w Kolbuszowej podjął się prezentacji powstańców styczniowych - Sybiraków z Kolbuszowej i okolic. Kolejnym prelegentem był kierownik Miejskiej i Gminnej Biblioteki Publicznej w Sokołowie Małopolskim dr Bartosz Walicki. Posiłkując się pokazem slajdów, przybliżył on słuchaczom temat sokołowskich epizodów powstania styczniowego. Na koniec 
odczytany został wykład prof. dr hab. Magdaleny Micińskiej z Polskiej Akademii Nauk. Poruszono w nim zagadnienie powstańców styczniowych uwolnionych z zesłania dzięki rozlicznym zabiegom ks. Ludwika Ruczki.

Podsumowania konferencji dokonał dr hab. Jacek Gołębiowski. Wspomnieć warto, że spotkanie było połączone z promocją dwóch publikacji związanych z nim tematycznie. Były to: książka prof. Magdaleny Micińskiej Ksiadz Ludwik Ruczka (1814-1896). Opiekun sybiraków z 1863 roku, polityk galicyjski, proboszcz Kolbuszowej $j^{5}$ oraz opracowanie Krzysztofa Haptasia Ksiadz Ludwik Rucz$k a(1814-1896)^{6}$. Krótka relacja z wydarzenia zamieszczona została na łamach „Niedzieli Rzeszowskiej”"

${ }^{5}$ M. Micińska, Ksiądz Ludwik Ruczka (1814-1896). Opiekun sybiraków z 1863 roku, polityk galicyjski, proboszcz Kolbuszowej, Warszawa 2015, ss. 267, [1], [16 tabl.].

${ }^{6}$ K. Haptaś, Ksiądz Ludwik Ruczka (1814-1896), Kolbuszowa 2015, ss. 46, [2].

${ }^{7}$ B. Walicki, Ojciec Sybiraków, „Niedziela Rzeszowska”, 2016, nr 7, s. VI-VII. 